\title{
Prevalence of Sports Practice among Mexican Adults in 2002 and 2014
}

\section{Prevalencia de la Práctica Deportiva en Adultos Mexicanos en 2002 y 2014}

\author{
Luis Ortiz-Hernandez*, Carolina Ayala Hilario, and César Iván Ayala- Guzmán
}

Universidad Autónoma Metropolitana Xochimilco, México.

\begin{abstract}
The aim of our study was to know the change over time of sports practice prevalence in Mexican adults and its socio-demographic correlates. We analyzed the Mexican National Survey of Time Use (ENUT) conducted in 2002 and 2014; which is based on a representative sample of Mexican adults. Through a questionnaire, it was inquired if people practised sport in the previous week of the interview and the time spent to do it. The independent variables were sociodemographic characteristics. We found that the prevalence of sports practice increased between 2002 and 2014 (from $15.8 \%$ to $29.3 \%$ ). Being single or having a high socioeconomic position was associated with a higher probability of sports practice. Men and city dwellers had higher probabilities of practice sport compared with their counterparts; although these differences tended to decrease. We conclude that the prevalence of sports practice in Mexico has increased, but it remains low. We identified groups with lower probabilities to practice sport in which efforts can be focused to promote active lifestyles.

Keywords: physical activity, inequalities, Mexico, surveys.
\end{abstract}

Resumen: El objetivo del estudio fue conocer el cambio en la prevalencia de la práctica deportiva en adultos mexicanos y su asociación con características sociodemográficas. Analizamos la Encuesta Nacional de Uso del Tiempo (ENUT) de México realizada en 2002 y 2014. A través de un cuestionario se indagó la práctica deportiva en la semana previa. Las variables independientes fueron las características sociodemográficas. Encontramos que la prevalencia de la práctica deportiva aumentó entre 2002 y 2014 (de $15.8 \%$ a $29.3 \%$ ). Ser soltero o tener una posición socioeconómica alta se asoció con una mayor probabilidad de práctica deportiva. Los hombres y los habitantes de las ciudades tenían mayores probabilidades de practicar deporte en comparación con sus contrapartes; aunque estas diferencias tendieron a disminuir. Concluimos que la prevalencia de la práctica deportiva ha aumentado, sin embargo, sigue siendo baja. Identificamos grupos con menor probabilidad de practicar deportes en los que se pueden enfocar esfuerzos para promover la actividad física.

Palabras clave: actividad física, desigualdades, México, encuestas.

\section{Introduction}

Physical inactivity is considered (Lee, Shiroma, Lobelo, Puska, Blair \& Katzmarzyk, 2012) one of the most important risk factors in Mexico because it is associated with the appearance and lack of control of different chronic diseases such as obesity, hypertension, diabetes mellitus, osteoporosis, and certain types of cancer. In Mexico, physical inactivity is a risk factor that contributes to $6.2 \%$ of mortality from coronary heart disease, $7.7 \%$ from type 2 diabetes mellitus, $10.0 \%$ from breast cancer, $11.2 \%$ from colon cancer, and $10.1 \%$ from overall mortality (Lee et al., 2012). Furthermore, physical inactivity has been parallel to the increase in obesity rate observed in recent decades.

According to its purpose, physical activity is classified in occupational (i.e. include daily activities such as work, transport activities, going to school, home activities) and discretionary activities (i.e. activities that are important for health, recreation and socialization) (Food and Agriculture Organization of the United Nations, World Health Organization, \& United Nations University, 2001). In most countries, industrialization and urbanization have implied changes in their occupational structure, i.e. jobs required considerable physical effort (e.g. farming) are less common, while jobs that require lower energy expenditure (e.g. manufacture)

Dirección para correspondencia [Correspondence address]: Luis OrtizHernandez.E-mail: lortiz@correo.xoc.uam.mx or sedentary jobs (e.g. trade and services) are more frequent (Ortiz-Hernandez, Delgado-Sanchez, \& Hernandez-Briones, 2006). In this way, the contribution of occupational physical activity to energy expenditure is less relevant, and physical activity that people perform will depend on discretionary activities (especially sport and recreation). Furthermore, there is evidence that physical activity at work is not associated to body mass (Gutierrez, Guallar-Castillon, Diez-Ganan, Lopez, Banegas \& Rodríguez, 2002) whereas, body mass is associated with sport or exercise practice (Garber, Blissmer, Deschenes, Franklin, Lamonte, Lee, Nieman \& Swain, 2011).

In high-income countries, the sports practice in adults has increased while occupational physical activity seems to be decreasing (Centers for Disease Control and Prevention \& National Center for Health Statistics [CDC/NCHS], 2015; Knuth \& Hallal, 2009). Whereas in middle-income countries, there are few studies that have done comparisons through the years to identify changes in the practice of overall physical activity and sport (Monteiro, Conde, Matsudo, Matsudo, Bonseñor \& Lotufo, 2003; Ng, Howard, Wang, Su, \& Zhang, 2014). In Mexico, there are estimations of sports practice prevalence in the adult population (Instituto Nacional de Estadistica y Geografía [INEGI], 2014b; Hernandez, Haene, Barquera, Monterrubio, Rivera, Shamah, Sepulveda, Haas \& Campirano, 2003; Rodríguez, Salazar, \& Cruz, 2013) but the information about the changes of it through the years is 
scarce. In the National Health and Nutrition Examination Survey of 2006 and 2012 the changes in the total physical activity of Mexican population aged over 20 years were analyzed (Medina, Janssen, Campos, \& Barquera, 2013). However, in this study different types of physical activity were not distinguished (i.e. occupational versus discretionary activities).

The ecological framework (Davison \& Birch, 2001) posits that health behaviors are determined by the context of individuals. Gender norms (García-Ferrando \& Llopis, 2011; Monteiro et al., 2003; Ortiz-Hernández \& Ramos-Ibanez, 2010; Salles-Costa, Heilborn, Werneck, Faerstein, \& Lopes, 2003) or social roles related with marital status (Secretaria de Educación Pública [SEP], 2015; Brown \& Trost, 2003; Ortega, Brown, Lee, Baruth, Sui \& Blair, 2010) or age (Arribas Galarraga, Gil de Montes Echaide, \& Arruza Gabilondo, 2012; Barnett, van Sluijs, \& Ogilvie, 2012; Hellín, Moreno, \& Rodríguez, 2004; Martínez-Ros, Tormo, Pérez-Flores, \& Navarro, 2003; Uribe-Bustos \& Agudelo-Calderón, 2011) can affect the possibility of practice any sport. Additionally, low socioeconomic could be related to different barriers to sports practice (Beenackers, Kamphuis, Giskes, Brug, Kunst, Burdof \& Van Lenthe, 2012; García-Ferrando \& Llopis, 2011; Grzywacz \& Marks, 2001; Hernandez et al., 2003; OrtizHernández \& Ramos-Ibanez, 2010).

Knowing the prevalence of sports practice in the Mexican population and identifying the groups with lower probabilities of sports practice can inform the design of policies and programs aimed to promote physical activity. Furthermore, knowing the changes over time in the sports practice allows us to realize the evolution of disparities related to this health behavior. Therefore, the objectives of this study were to know the change over time of sports practice in Mexican adults between 2002 and 2014 and to analyze the relationship between sports practice and sociodemographic characteristics of the participants.

\section{Methods}

\section{Design, procedures, and participants}

Databases of the National Time Use Survey (ENUT by its acronym in Spanish: Encuesta Nacional de Usos del Tiempo) of Mexico carried out in 2002 and 2014 were analyzed. ENUT is a cross-sectional survey with a probabilistic, two-stage, stratified and by clustering sampling design (INEGI, 2002, 2014a). The fieldwork of the ENUT 2002 was conducted in November and December, and the ENUT 2014 was conducted in October and November. Representative samples of the 12 years old people and older are obtained in each version of ENUT. Total samples of participants were 20,342 in 2002 and 42,118 in 2014. Our analysis was restricted to adults 20 to 60 years old, therefore the analytical samples were formed by 9,486 and 29,617 participants, respectively. The informa- tion was obtained through a questionnaire administered by trained interviewers.

The ENUT is part of the governmental system of information; therefore, participation in the survey is compulsory (INEGI, 2002, 2014a). In spite of it, verbal informed consent was obtained from participants. The objectives, design, and ethics of the study (which implied the use of the ENUT database) was approved by the Divisional Council of Biological and Health Sciences of the Universidad Autonoma Metropolitana at Xochimilco.

\section{Variables}

The independent variables were household head education, locality size, geographic region and sociodemographic characteristics of the participants. The household head education was considered a proxy of socioeconomic position and was classified into five categories: none, primary education, junior high school, high school, bachelor or postgraduate. The locality size was classified in four categories: cities $(100,000$ or more inhabitants), urban localities (15,000 to 99,999); mixed localities $(2,500$ to 14,999$)$ and rural (less than 2,500). Four geographical regions were created based on the state where participants lived: north (Coahuila, Nuevo León, Tamaulipas, Baja California, Baja California Sur, Chihuahua, Durango, Sinaloa and Sonora), western (Colima, Nayarit, Michoacán, Jalisco, Aguascalientes, Guanajuato, Querétaro, San Luis Potosí and Zacatecas), central (Ciudad de México, Estado de México, Morelos, Hidalgo, Puebla and Tlaxcala), and south (Campeche, Quintana Roo, Tabasco, Yucatán, Chiapas, Guerrero, Oaxaca and Veracruz) and. Age, sex and marital status of participants were analyzed too. The latter was grouped into four categories: single, married or cohabiting, divorced or separated, and widowed.

Whether people performed physical activity in the past week is asked in the ENUT. The question in 2002 was: "In the last week did you exercise, play or practice sport? (not to include whether it is for work or study)", while in 2014, the question was: "During the past week, in your leisure time did you practice sport or exercise? (football, basketball, swimming, boxing, karate, walking, running, skating, cycling, yoga, Zumba)". If the answer was positive, the interviewers inquired about duration (i.e. hours and minutes per week) for weekdays (Monday to Friday) and weekends (Saturday and Sunday) of practice sport.

\section{Data Analyses}

All statistical analyses were performed using STATA software version 13.0. Estimates were made using the surveys commands (svy), whereby the complex design (i.e. probabilistic, two-stage, stratified and cluster sampling) of the ENUT 
was considered. Absolute and relative frequencies of the variables under study were obtained (Tables 1 and 2). Differences between groups were analyzed using Chi-squared (for categorical variables) and T-Student (for continuous variables) statistics. Then, logistic regression models were estimated, in which the outcome was sports practice; while independent variables were household head education, locality size, geographic region and sociodemographic characteristics of participants (Table 3). Interaction terms of these variables with the survey year were included in the models. When there were significant interactions $(p<0.100)$, we estimated and plotted the adjusted probabilities of sports practice (Figure 1).

\section{Results}

The sociodemographic characteristics of Mexican adults are shown in Table 1. In 2004 and 2012 around half of the Mexican adults were women, the most common age group was 20 to 30 years old and the less common was 51 to 60 years old. The highest proportion of people were married, resided in localities with more than 100,000 inhabitants or $\mathrm{t}$ the central region. During the period under study, the proportions of people aged between 40 and 60 years, divorced persons and those with high school or more increased.

Table 1. Sociodemographic characteristics of Mexican adult population in 2002 and 2014.

\begin{tabular}{lcc}
\hline & 2002 & 2014 \\
\hline $\mathrm{n}$ & 9,486 & 28,547 \\
$\mathrm{~N}^{\mathrm{a}}$ & $48,961,494$ & $63,585,552$
\end{tabular}

$\begin{array}{lccc} & \%^{\mathrm{a}} & \%^{\mathrm{a}} & \mathrm{p}^{\mathrm{b}} \\ \text { Sex } & 46.8 & 46.1 & 0.473 \\ \text { Men } & 53.2 & 53.9 & \\ \text { Women } & & & \\ \text { Age (years) } & 35.8 & 32.7 & 0.003 \\ 20-30 & 28.9 & 27.0 & \\ 31-40 & 20.3 & 23.5 & \\ 41-50 & 15.0 & 16.7 & \\ \text { 51-60 } & & & \\ \text { Marital status } & 21.5 & 22.4 & 0.002 \\ \text { Single } & 70.6 & 67.7 & \\ \text { Married or cohabiting } & 5.2 & 7.9 & \\ \text { Divorced or separated } & 2.7 & 2.0 & \\ \text { Widowed } & & & \\ \text { Household head education } & 13.8 & 6.7 & 0.000 \\ \text { None } & 40.5 & 32.5 & \\ \text { Elementary } & & \end{array}$

\begin{tabular}{lccc}
\hline & 2002 & 2014 & \\
\hline Junior high school & 22.9 & 278.1 & \\
High school & 10.3 & 16.3 & \\
Bachelor or postgraduate & 12.5 & 16.5 & \\
Locality size (inhabitants) & & & \\
Cities & 52.8 & 51.2 & 0.085 \\
Urban & 13.9 & 14.8 & \\
Mixed & 11.6 & 13.6 & \\
Rural & 21.7 & 20.4 & \\
Region & & & \\
North & 21.6 & 23.1 & 0.914 \\
Western & 21.0 & 22.5 & \\
Central & 35.0 & 32.6 & \\
South & 22.4 & 21.9 & \\
\hline
\end{tabular}

n, sample size; N, estimated population; ${ }^{a}$ weighted estimates. ${ }^{2}$ chi-squared test for comparisons between years.

Between 2002 and 2014, the proportion of people who practiced sport increased as well as the average time dedicated to doing it (Table 2). In both years, men spent more time doing sport compared to women. Nevertheless, differences in 2014 were lower than in 2002. For example, in 2002 men spent 2.51 times more minutes doing sport than women $(63.12$ and 25.10 minutes per week, respectively), while in 2014 the ratio decreased to 1.56 (95.18 and 60.97 minutes per week, respectively). Compare with older people (e.g. 51-60 years old), among younger people (aged 20 to 30 years), the sports practice prevalence was higher $(19.9 \%$ versus $13.5 \%$ in 2002 , respectively), and they dedicated more minutes to practice it (57.40 and 34.87 minutes per week, respectively). Single people spent more time practicing a sport than other groups defined by marital status. For example, in 2014 widowed participants spent 50.89 minutes per week, whereas in single participants the time was 125.25 minutes per week.

People with higher socioeconomic position (assessed by household head education) spent more time to practice sport; however, differences in 2014 were lower than in 2002. For instance, in 2002, people without education spent $24.89 \mathrm{mi}$ nutes per week, and people with a bachelor or more education spent 90.01 minutes per week; for 2014 the time was 49.45 and 126,30, respectively. People residing in cities dedicated more time to practice sport than people that lived in smaller localities, however differences in 2014 (55.34 and $23.21 \mathrm{mi}-$ nutes per week in cities and rural localities, respectively) were lower than in 2002 (86.96 and 53.11 minutes per week, respectively). In 2002 there were no differences between regions, however, in 2014 inhabitants of the south dedicated less time (61.98 minutes per week) to practice sport than other regions (for example, in the central region the time was $78.17 \mathrm{minu}-$ tes per week). 
Table 2. Prevalence of sports practice in Mexican adults (2002 and 2014) according to sociodemographic characteristics

\begin{tabular}{|c|c|c|c|c|c|c|}
\hline & \multicolumn{3}{|c|}{$2002(n=9,486)$} & \multicolumn{3}{|c|}{$2014(\mathrm{n}=28,547)$} \\
\hline & $\%$ & $p$ & $\begin{array}{c}\text { Time } \\
\text { (min/week) }\end{array}$ & $\%$ & $p$ & $\begin{array}{c}\text { Time } \\
\text { (min/week) }\end{array}$ \\
\hline Total & 15.8 & & 42.90 & 29.3 & & 76.74 \\
\hline \multicolumn{7}{|l|}{ Sex } \\
\hline Men & 23.2 & 0.000 & 63.12 & 35.3 & 0.000 & 95.18 \\
\hline Women & 9.4 & & $25.10^{\mathrm{a}}$ & 24.1 & & $60.97^{a}$ \\
\hline \multicolumn{7}{|l|}{ Age (years) } \\
\hline $20-30$ & 19.9 & 0.008 & 57.40 & 35.4 & 0.000 & 103.7 \\
\hline $31-40$ & 14.9 & & $35.48^{a}$ & 25.8 & & $63.51^{\mathrm{a}}$ \\
\hline $41-50$ & 11.6 & & $33.77^{a}$ & 27.8 & & $66.78^{\mathrm{a}}$ \\
\hline $51-60$ & 13.5 & & 34.87 & 25.2 & & $59.37^{a}$ \\
\hline \multicolumn{7}{|l|}{ Marital status } \\
\hline Single & 25.3 & 0.000 & 76.02 & 40.4 & 0.000 & 125.25 \\
\hline Married or cohabiting & 13.6 & & $34.95^{a}$ & 26.1 & & $62.16^{\mathrm{a}}$ \\
\hline Divorced or separated & 10.1 & & $29.95^{\mathrm{a}}$ & 26.8 & & $70.51^{a}$ \\
\hline Widowed & 8.24 & & $22.92^{\mathrm{a}}$ & 22.2 & & $50.89^{\mathrm{a}}$ \\
\hline \multicolumn{7}{|l|}{ Household head education } \\
\hline None & 7.9 & 0.000 & 24.89 & 18.9 & 0.000 & 49.45 \\
\hline Elementary & 11.5 & & 32.32 & 23.7 & & 60.97 \\
\hline Junior high school & 17.7 & & $43.90^{\text {a }}$ & 27.4 & & 66.57 \\
\hline High school & 20.2 & & 48.99 & 32.4 & & $85.18^{a, b, c}$ \\
\hline Bachelor or postgraduate & 31.3 & & $90.01^{\mathrm{a}, \mathrm{b}, \mathrm{c}, \mathrm{d}}$ & 44.4 & & $126.30^{\mathrm{a}, \mathrm{b}, \mathrm{c}, \mathrm{d}}$ \\
\hline \multicolumn{7}{|l|}{ Locality size } \\
\hline Cities & 20.6 & 0.000 & 55.34 & 32.3 & 0.000 & 86.96 \\
\hline Urban & 14.0 & & $37.44^{\mathrm{a}}$ & 30.2 & & 79.99 \\
\hline Mixed & 12.2 & & $29.57^{\mathrm{a}}$ & 28.5 & & 70.30 \\
\hline Rural & 7.19 & & $23.21^{\mathrm{a}}$ & 21.5 & & $53.11^{\mathrm{a}, \mathrm{b}, \mathrm{c}}$ \\
\hline \multicolumn{7}{|l|}{ Regions } \\
\hline North & 17.9 & 0.123 & 46.44 & 29.4 & 0.000 & 80.89 \\
\hline Western & 15.4 & & 44.62 & 32.6 & & 84.79 \\
\hline Central & 17.4 & & 44.52 & 30.8 & & 78.17 \\
\hline South & 11.8 & & 35.35 & 23.5 & & $61.98^{\mathrm{a}, \mathrm{b}, \mathrm{c}}$ \\
\hline
\end{tabular}

min/week, minutes per week. a significant difference from men, 20-30 years, single, none education, cities, or north region, respectively.

${ }^{\mathrm{b}}$ significant difference from elementary school, urban, or western region, respectively. ${ }^{\mathrm{c}}$ significant difference from junior high school, mixed localities, or central region, respectively. ${ }^{\mathrm{d}}$ significant difference from high school. Superscripts mean that $95 \%$ confidence intervals (estimated through Taylor series linearization method) do not overlap.

After adjusting by other covariates, it was observed that 31 to 60 years old adults had less probability of sports practice compared to younger adults $(\mathrm{OR}=0.76$, see Table 3$)$. Being married, divorced or widowed was related to less probability of sports practice compared to single adults. Higher house- hold head education was associated with a higher probability of sports practice. People from the west region had the highest probability of sports practice compared to other geographical regions. 
Table 3. The logistic regression model in which the outcome is the sports practice and exposure variables are sociodemographic characteristics.

\begin{tabular}{|c|c|c|}
\hline & OR & $95 \% \mathrm{CI}$ \\
\hline \multicolumn{3}{|l|}{ Year of the survey ${ }^{\text {a }}$} \\
\hline 2014 & 0.67 & $0.42-1.06$ \\
\hline \multicolumn{3}{|l|}{ Sex ${ }^{b}$} \\
\hline Women & 0.34 & $0.25-0.45$ \\
\hline Year of the survey ${ }^{*}$ sex & 1.69 & $1.27-2.24$ \\
\hline \multicolumn{3}{|l|}{ Age (years) ${ }^{c}$} \\
\hline $31-40$ & 0.76 & $0.66-0.89$ \\
\hline $41-50$ & 0.76 & $0.68-0.86$ \\
\hline $51-60$ & 0.79 & $0.68-0.92$ \\
\hline \multicolumn{3}{|l|}{ Household head education ${ }^{d}$} \\
\hline Elementary & 1.36 & $1.15-1.59$ \\
\hline Junior high school & 1.75 & $1.48-2.08$ \\
\hline High school & 2.06 & $1.73-2.46$ \\
\hline Bachelor or postgraduate & 3.65 & $2.95-4.78$ \\
\hline \multicolumn{3}{|l|}{ Marital status ${ }^{\mathrm{e}}$} \\
\hline Divorced or separated & 0.65 & $0.53-0.80$ \\
\hline Widowed & 0.60 & $0.45-0.79$ \\
\hline Married or cohabiting & 0.56 & $0.48-0.65$ \\
\hline \multicolumn{3}{|l|}{ Locality size ${ }^{f}$} \\
\hline Urban & 0.81 & $0.69-0.96$ \\
\hline Mixed & 0.68 & $0.53-0.89$ \\
\hline Rural & 0.41 & $0.28-0.61$ \\
\hline Year of the survey * locality size & 1.25 & $1.10-1.43$ \\
\hline \multicolumn{3}{|l|}{ Regions $\mathrm{g}$} \\
\hline North & 0.81 & $0.70-0.94$ \\
\hline Central & 0.85 & $0.75-0.97$ \\
\hline South & 0.72 & $0.63-0.82$ \\
\hline
\end{tabular}

Note. OR, odds ratio; 95\%CI, 95\% confidence interval. Reference groups: ${ }^{\mathrm{a}}$ participants in the survey carried out in $2002,{ }^{\mathrm{b}}$ men, ${ }^{\mathrm{c}} 20$ 30 years old, ${ }^{\mathrm{d}}$ without education, ${ }^{\mathrm{e}}$ single, ${ }^{\mathrm{f}}$ cities, and ${ }^{\mathrm{g}}$ west region.

Interactions of sex and locality size with the survey year were significant (Table 3), and hence the probabilities of sports practice were graphed (Figure 1). In women, the probability of sports practice increased $181.2 \%$ (from 0.085 in 2002 to 0.239 in 2014), while in men the increase was lower (67.6\%). The result of these trends was that the difference between sexes decreased from 2.47 in 2002 (probabilities ratio: $0.210 / 0.085$ ) to 1.47 in 2014 (probabilities ratio: $0.352 / 0.239$, see Figure 1.a). Among people from rural localities, the increase of probability of sports practice was higher $(213.0 \%)$ than among those from cities $(62.6 \%)$, which produced that differences among this groups decreased (from a probabilities ratio of 2.87 in 2002 to 1.49 in 2014, see Figure 1.b).

1.a. Interaction of survey year with sex

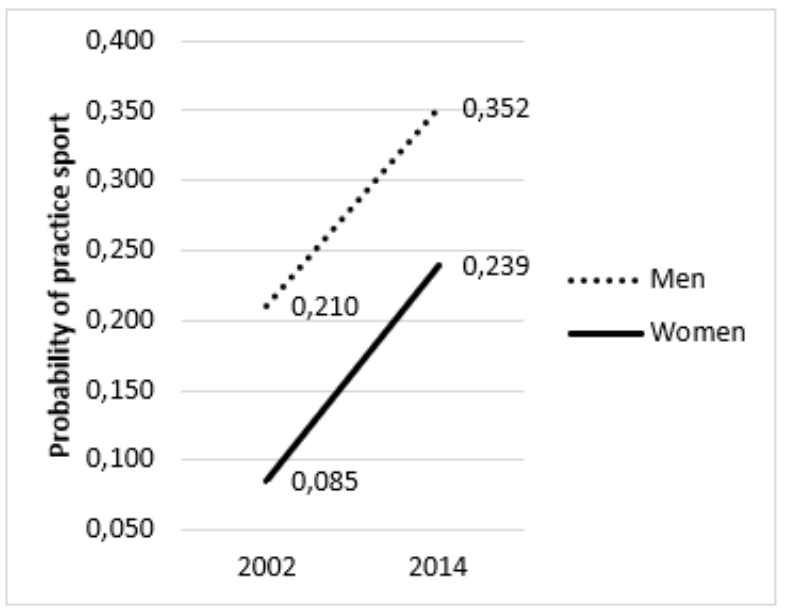

1.b. Interaction of survey year with locality size

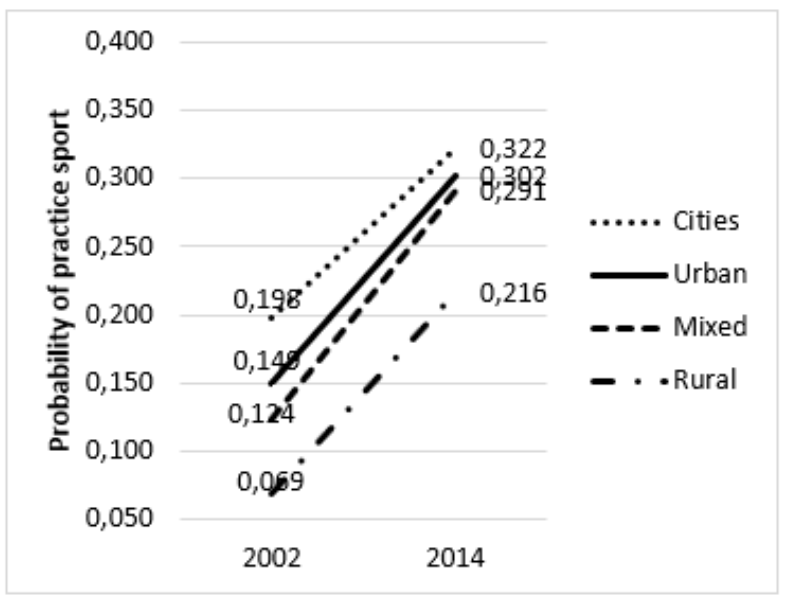

Figure 1. Interaction of survey year with sex, household head education and locality size to predict the probability of practice sport.

\section{Discussion}

One objective of this study was to know the changes in sports practice prevalence among Mexican adults between 2002 and 2014. We found that the prevalence of sports practice doubled during this period but keep low, even after adjusting for demographics (sex, gender, socioeconomic position, and locality size). Another aim of the study was to analyzed sociodemographic correlates of sports practice. Furthermore, during this period disparities by socioeconomic position, sex and locality size had been reduced. In both years, the sports practice prevalence was higher in younger people and in tho- 
se who were single. The western region of Mexico had the highest rate of sports practice.

Among Mexican adults, the prevalence of sports practice has increased. In contrast, in an analysis of the National Health and Nutrition Examination Survey (ENSANUT by its acronym in Spanish: Encuesta Nacional de Salud y Nutrición) of Mexico (Medina et al., 2013), the reduction of physical activity level between 2006 and 2012 was observed. In that study, total physical activity was estimated, therefore the contribution of specific forms of physical activity was not done. The reduction of physical activity level observed in the ENSANUT could be due to a change in occupational and transport activities.

Just as it has occurred in high-income countries (CDC/ NCHS, 2015;Knuth \& Hallal, 2009), more adults practice sport in Mexico. A possible explanation for this finding is that public and private infrastructure have grown (OrtizHernández, 2005), as well as the implementation of government programs aimed to promote sports (SEP, 2015). However, in spite of its increasing, the prevalence of sports practice in Mexican adults (29.3\% in 2014) remains low when compared with populations from high-income countries. For example, $81 \%$ of Danish women and $77 \%$ of Swedish men practice sport (Sisson \& Katzmarzyk, 2008); whereas the rates for British men and women were $60.8 \%$ and $46.0 \%$ (Jones, Millward, \& Buraimo, 2011). According to Eurobarometer (European Commission, 2014), in 2013, the rate of sport participation was $69 \%$ in Belgium, $71 \%$ in Germany and $73 \%$ in the Netherlands.

Our results confirm the existence of disparities associated with socioeconomic position (Beenackers et al., 2012; GarcíaFerrando \& Llopis, 2011; Grzywacz \& Marks, 2001; Hernandez et al., 2003; Ortiz-Hernández \& Ramos-Ibanez, 2010) and gender (García-Ferrando \& Llopis, 2011; Monteiro et al., 2003; Ortiz-Hernández \& Ramos-Ibanez, 2010; Salles-Costa et al., 2003): women and people with low socioeconomic position have lower probabilities of practice sport than their counterparts. At the same time, this study shows that in Mexico, gender and socioeconomic inequities have decreased in recent years. A possible explanation for the reduction of differences between sexes is that gender stereotypes have become more flexible, therefore sports progressively are less a masculine domain (Appleby \& Foster, 2013). Furthermore, the new stereotype of women's beauty is not only in being thin, but also have muscle tone (Spencer, Rehman, \& Kirk, 2015).

Regarding socioeconomic inequities in sports practice, it is well known that people with low socioeconomic position may face more difficulties to practice it, in which some barriers are: fewer recreational in the areas where they live (Ortiz-Hernández, 2005), lack of resources to access to private services, and have less time for recreational activities (GarcíaFerrando \& Llopis, 2011; Seefeldt, Malina, \& Clark, 2002).
In Mexico, the growth of private sports facilities has occurred in counties with better socioeconomic conditions (OrtizHernández, 2005). Given these facts, we hypothesized that socioeconomic differences in sports practice among Mexican adults would increase. However, in twelve years differences by household head education in sports practice have kept. It is possible that government programs (e.g. outdoor gyms or mass communication programs about benefits of physical activity) that promote sports practice have prevented an increase in the socioeconomic disparities.

Age was another demographic related to sports practice: younger people had less probability to practice it. Age has been negatively related to sports practice in other populations (Arribas Galarraga et al., 2012; Barnett et al., 2012; Hellín et al., 2004; Martínez-Ros et al., 2003; Uribe-Bustos \& Agudelo-Calderón, 2011). Interestingly, we found that among people of 30 years and older there were no differences by age in the time spent to sports practice, i.e. no differences between 31 to 40,41 to 50 , and 51 to 50 years old groups. Even, in 2002, the prevalence of sports practice was higher in the 51-60 group compared to the $41-50$ group. It is possible that the reduction of sports practice associated with age is offset by the increase of physical activity which happens with retirement. Thus, when leaving the labor market, people have more time available to do recreational (Knuth \& $\mathrm{Ha}$ llal, 2009; Rodríguez et al., 2013). In addition, because aging and the experience of chronic disease, older people become to practice sports as a part of self-care activities (Arribas Galarraga et al., 2012; Hellín et al., 2004).

With the ENUT data, it was noted that sports practice was more frequent among single adults, which was also reported in other studies (SEP, 2015; Brown \& Trost, 2003; Ortega et al., 2010). Regarding women, housework and child rearing as a consequence of marriage can result in reduced time for recreational activities (Brown \& Trost, 2003). A follow-up study showed that participants reduced their fitness after getting married, while the divorce is associated with a slight increase in sports practice, especially in men (Ortega et al., 2010). In another study, men who re-married exhibited decreased physical activity (Eng, Kawachi, Fitzmaurice, \& Rimm, 2005).

Living in urban areas and in the Western region were related to higher probabilities of practice sport. In urban areas, sports practice has emerged as a way to replace the physical activity that previously was performed in agricultural or industrial occupations (Ng et al., 2014). For this reason, sports facilities availability usually is higher in urban areas. Interestingly, this study has documented that in recent years the increase in sports practice has been higher in rural areas. In addition to government programs that promote exercise, it is also possible that people living in rural areas have reduced agricultural work or it has been automatized, so they have 
sought to perform physical activity in their leisure time. Finally, it is possible that states in the Western region have promoted sports.

A strength of this study is that we analyzed the change over time in the prevalence of sports practice using a representative survey of the Mexican population. At the same time, this research has some limitations that should be considered for the interpretation of the results. Despite the fact that the ENUT is intended to offer data about the allocation of time to different activities, it should be noted that this survey does not reveal in detail important aspects of sports practice as the type of sport, intensity, and regularity with which it is done. In addition, the use of questionnaires to assess physical activity has been questioned because people tend to overestimate moderate and vigorous activities (Medina, Barquera, \& Janssen, 2013).
Data of trends in the prevalence of sports practice are scarce, and this situation is especially true to low or middleincome countries (Knuth \& Hallal, 2009). We show that the proportion of Mexican adults who practice sport increased between 2002 and 2014. However, this prevalence remains low because only a third of people do sport. We also identified groups with a low probability of sports practice: women, people of low socioeconomic position, people over age 30 , married, or living in rural areas and in regions different to the Western. Efforts should be concentrated to promote sports practice in these groups. More research is needed about the factors that have influenced the reduction of disparities by gender and locality size in order to develop policies and programs to promote sports practice among women and people from rural areas.

\section{References}

1. Appleby, K. M., \& Foster, E. (2013). Gender and sport participation. In E. Roper (Ed.), Gender relations in sport (pp. 1-20). Rotterdam, The Netherlands: Sense Publishers.

2. Arribas G. S., Gil de Montes. L., \& Arruza G. J. A. (2012). Panorámica de la práctica física y deportiva en Gipuzkoa: Servicio Editorial de la Universidad del País Vasco/Euskal Herriko Unibertsitatearen Argitalpen Zerbitzua

3. Barnett, I., van Sluijs, E. M., \& Ogilvie, D. (2012). Physical activity and transitioning to retirement: a systematic review. American Journal of Preventive Medicine, 43 (3), 329-336.

4. Beenackers, M. A., Kamphuis, C., Giskes, K., Brug, J., Kunst, A. E., Burdorf, A., \&Van Lenthe, F. J. (2012). Socioeconomic inequalities in occupational, leisure-time, and transport related physical activity among European adults: a systematic review. International Journal of Behavior Nutrition \& Physical Activity, 9 (1), 116.

5. Brown, W. J., \& Trost, S. G. (2003). Life transitions and changing physical activity patterns in young women. American Journal of Preventive Medicine, 25(2), 140-143.

6. Centers for Disease Control and Prevention \& National Center for Health Statistics. (2015). Early release of selected estimates based on data from the January-March 2014 National Health Interview Survey. U.S. Department of Health and Human Services, Centers for Disease Control and Prevention, National Center for Health Statistics. Retrieved 10th January 2017 from https://www.cdc.gov/nchs/data/nhis/ earlyrelease/earlyrelease201409.pdf

7. Food and Agriculture Organization of the United Nations, World Health Organization, \& United Nations University (2001). Human energy requirements (Vol. 1). Roma: United Nations University, World Health Organization, Food and Agriculture Organization of the United Nations.

8. Davison, K. K., \& Birch, L. L. (2001). Childhood overweight: a contextual model and recommendations for future research. Obes Rev, 2(3), 159-171.

9. Eng, P. M., Kawachi, I., Fitzmaurice, G., \& Rimm, E. B. (2005). Effects of marital transitions on changes in dietary and other health behaviours in US male health professionals. J Epidemiol Community Health, 59(1), 56-62.

10. European Commission. (2014). Special eurobarometer 412. Sport and physical activity. Brussels, Belgium: European Commission, Directorate-General for Education and Culture and co-ordinated by DirectorateGeneral for Communication.
11. Garber, C. E., Blissmer, B., Deschenes, M. R., Franklin, B. A., Lamonte, M. J., Lee, I. M., Nieman, D. C., \& Swain, D. P. (2011). American College of Sports Medicine position stand. Quantity and quality of exercise for developing and maintaining cardiorespiratory, musculoskeletal, and neuromotor fitness in apparently healthy adults: guidance for prescribing exercise. Medicine, Science Sports \& Exercise, 43(7), 1334-1359.

12. García-Ferrando, M., \& Llopis, R. (2011). Ideal democrático y bienestar personal. Encuesta sobre los hábitos deportivos en España 2010. Madrid: Centro de Investigaciones Sociológicas-Consejo Superior de Deportes.

13. Grzywacz, J. G., \& Marks, N. F. (2001). Social inequalities and exercise during adulthood: toward an ecological perspective. Journal of Health \& Social Behavior, 42(2), 202-220.

14. Gutierrez-Fisac, J. L., Guallar-Castillon, P., Diez-Ganan, L., Lopez, G. E., Banegas, B. J. R., \& Rodriguez, A. F. (2002). Work-related physical activity is not associated with body mass index and obesity. Obesity Research, 10(4), 270-276.

15. Hellín, P., Moreno, J. A., \& Rodríguez, P. L. (2004). Motivos de práctica físico-deportiva en la Región de Murcia. Cuadernos de psicología del deporte, 4(1-2), 101-116.

16. Hernandez, B., de Haene, J., Barquera, S., Monterrubio, E., Rivera, J., Shamah, T., Sepulveda, J., Haas, J., \& Campirano, F. (2003). Factors associated with physical activity among Mexican women of childbearing age. Revista Panamericana de Salud Publica, 14(4), 235-245.

17. Instituto Nacional de Estadística y Geografía. (2002). Encuesta Nacional sobre Uso del Tiempo 2002. Retrieved 25 November, 2015 from http://www.inegi.org.mx/est/contenidos/proyectos/encuestas/hogares/ especiales/enut/enut2002/default.aspx

18. Instituto Nacional de Estadística y Geografía. (2014a). Encuesta Nacional sobre Uso del Tiempo 2014. Retrieved 25 November, 2015 from http://www.inegi.org.mx/est/contenidos/proyectos/encuestas/hogares/ especiales/enut/enut2014/default.aspx

19. Instituto Nacional de Estadística y Geografía. (2014b). Módulo de práctica deportiva y ejercicio físico. Retrieved 5 December, 2015 from http://www.inegi.org.mx/est/contenidos/proyectos/encuestas/hogares/ modulos/mopradef/

20. Jones, H., Millward, P., \& Buraimo, B. (2011). Adult participation in sport: analysis of the taking part survey. England: Department for Culture, Media and Sport. 
21. Knuth, A. G., \& Hallal, P. C. (2009). Temporal trends in physical activity: a systematic review. Journal of Physical Activity \& Health, 6(5), 548-559.

22. Lee, I. M., Shiroma, E. J., Lobelo, F., Puska, P., Blair, S. N., \& Katzmarzyk, P. T. (2012). Effect of physical inactivity on major non-communicable diseases worldwide: an analysis of burden of disease and life expectancy. Lancet, 380(9838), 219-229.

23. Martínez-Ros, M., Tormo, M., Pérez-Flores, D., \& Navarro, C. (2003). Actividad física deportiva en una muestra representativa de la población de la Región de Murcia. Gaceta Sanitaria, 17(1), 11-19.

24. Medina, C., Barquera, S., \& Janssen, I. (2013). Validity and reliability of the International Physical Activity Questionnaire among adults in Mexico. Revista Panamericana de Salud Publica, 34(1) 21-28.

25. Medina, C., Janssen, I., Campos, I., \& Barquera, S. (2013). Physical inactivity prevalence and trends among Mexican adults: results from the National Health and Nutrition Survey (ENSANUT) 2006 and 2012. BMC Public Health, 13(1), 1063.

26. Monteiro, C. A., Conde, W. L., Matsudo, S. M., Matsudo, V. R., Bonseńor, I. M., \& Lotufo, P. A. (2003). A descriptive epidemiology of leisure-time physical activity in Brazil, 1996-1997. Revista Panamericana de Salud Publica, 14(4), 246-254.

27. Ng, S. W., Howard, A. G., Wang, H., Su, C., \& Zhang, B. (2014). The physical activity transition among adults in China: 1991-2011. Obesity Reviews, 15(S1), 27-36.

28. Ortega, F. B., Brown, W. J., Lee, D.-c., Baruth, M., Sui, X., \& Blair, S. N. (2010). In fitness and health? A prospective study of changes in marital status and fitness in men and women. American Journal of Epidemiology, 173(3), 337--344.

29. Ortiz-Hernandez, L. (2005). Disparidad socioeconómica en la disponi- bilidad de infraestructura para actividad física deportiva en los municipios de México. Revista Salud Pública y Nutrición, 6, 21.

30. Ortiz-Hernandez, L., Delgado-Sanchez, G., \& Hernandez-Briones, A (2006). Cambios en factores relacionados con la transición alimentaria y nutricia en México. Gaceta Médica de México, 142(3), 181-193.

31. Ortiz-Hernández, L., \& Ramos-Ibanez, N. (2010). Sociodemographic factors associated with physical activity in Mexican adults. Public Health Nutrition, 13(7), 1131-1138.

32. Rodríguez, G. R. C., Salazar, C. J. d. J., \& Cruz, R. A. A. (2013). Determinantes de la actividad física en México. Estudios Sociales, 21(41), 185-209.

33. Salles-Costa, R., Heilborn, M. L., Werneck, G. L., Faerstein, E., \& Lopes, C. S. (2003). Gênero e prática de atividade física de lazer. Cadernos de Saúde Pública, 19, S325-S333.

34. Seefeldt, V., Malina, R. M., \& Clark, M. A. (2002). Factors affecting levels of physical activity in adults. Sport Medicine, 32(3), 143-168.

35. Secretaría de Educación Pública (2015). Programa S269 de cultura física y deporte. Secretaría de Educación Pública, Comisión Nacional de Cultura Física y Deporte. Retrieved 10th January 2017 from http:// www.transparenciapresupuestaria.gob.mx/work/models/PTP/Reingenieria_Gasto/imagenes/Ventanas/Ramo_11/11S269.pdf

36. Sisson, S., \& Katzmarzyk, P. (2008). International prevalence of physical activity in youth and adults. Obesity Reviews, 9(6), 606-614.

37. Spencer, R. A., Rehman, L., \& Kirk, S. F. (2015). Understanding gen der norms, nutrition, and physical activity in adolescent girls: a scoping review. International Journal of Behavior, Nutrition \& Physical Activity, 12,6 .

38. Uribe-Bustos, X., \& Agudelo-Calderón, C. (2011). Inactividad física y factores de riesgo: aproximación a un modelo interpretativo para Bogotá. Revista de Salud Pública, 13(4), 597-609. 